FACTA UNIVERSITATIS

Series: Law and Politics Vol. 18, N² 2020, pp. 117-130

https://doi.org/10.22190/FULP2002117N

Review Paper

\title{
CRIMINAL SANCTIONS IN DUŠAN'S CODE
}

UDC 343.222:343.8

\section{Anđelija Nešović}

\author{
Faculty of Law, University of Niš, Serbia
}

\begin{abstract}
Emperor Dušan's Code is the most important legal document of medieval Serbia, which is often considered to be the early Serbian "constitution". It is largely based on the Byzantine legal tradition, which entailed a rigorous system of criminal sanctions and diverse forms of punishment: death penalty by hanging and burning, mutilation of body parts, blinding, branding, scorching, cruel corporal punishment (beating, flogging), imprisonment, severe fines, confiscation of property, exile or banishment and dislocation as a form of collective punishment for the subjects. In this article, the author of presents and analyzes relevant provision of Dušan's Code, dealing with the envisaged criminal sanctions and different forms of punishment which were imposed on the perpetrators of criminal offences. The research methodology is based on normative, dogmatic and historical methods. Based on this analysis and comparison with the positive criminal legislation of the Republic of Serbia, the author concludes that Dušan's Code prescribed much more rigorous criminal sanctions, particularly given the fact that the current legislation law does not envisage death penalty and severe corporal punishment.
\end{abstract}

Key words: Dušan's Code, criminal sanctions, death penalty, corporal punishment, collective responsibility

\section{INTRODUCTION}

In the first half of the $14^{\text {th }}$ century, the political situation in the Balkans was very complex. The Byzantine Empire was in constant decline due to the growing economic crisis, the sharp depreciation of the value of money, the rising prices and the escalating poverty of population masses living on the verge of extreme misery. This situation in Byzantium affected the desire of the Serbian authorities for expansion. As the aspirations of the elderly king Stefan Dečanski did not correspond to those plans, the feudal lords wanted to bring his son Stefan Dušan to power, who proved his fighting spirit and courage in the fight against the Bulgarians.

Received July $14^{\text {th }} 2020 /$ Accepted September $21^{\text {st }} 2020$

Corresponding author: Anđelija Nešović, LL.M., PhD student at the Faculty of Law, University of Niš, Republic of Serbia. E-mail: andjelijanesovic018@gmail.com 
Stefan Dušan was crowned king in 1331. Thus, the Serbian feudal state got a young, energetic and capable military leader whose personal ambition completely corresponded to the aspirations of the ruler. As Serbia was at the peak of its strength, Tsar Dušan consistently pursued the goal of replacing the declining Byzantium with a powerful Serbian-Greek empire that would accept the tradition of the Byzantine Empire (Ostrogorski, 1969: 450). In the 14 ${ }^{\text {th }}$ century, Tsar Dušan was perhaps the most powerful ruler in Europe. After conquering large parts of southeastern Europe, he launched campaigns to conquer Byzantine lands, with the ultimate goal of reaching Constantinople. He proclaimed himself Emperor of the Serbs and Greeks, with a clear intent to establish the Serbian-Greek Empire as the successor of Byzantium. He pursued the mission with his ambitious nobleman, but his untimely death in a crusade against the Turks marked the beginning of the decline of the new empire (Ransimen, 1964: 284).

Besides being a protector of Christianity and a proponent of independence of the Serbian Orthodox Church, Emperor Dušan considered that one of the greatest duties of an emperor was legislative work. Thus, one of the most significant monuments of Emperor Dušan's rule was codification of a set of laws that regulated different aspects of life in the empire. Above all, it was supposed to be a confirmation of his right to the imperial crown and the power of the empire. Thus, Dušan's Code (1349) was a legal document aimed at ensuring the unification of the legal order in the entire state. It was extensively based on the Byzantine law, which was built into the foundations of the entire system of medieval Serbian law (Јанковић, 1962: 69). The Code includes provisions about the rule of the Emperor, the Church and civil law, but the largest part of the Code is dedicated to criminal law, rigorous criminal sanctions and diverse forms of punishment which were imposed on the perpetrators of criminal acts in medieval times, such as: death penalty by hanging and burning, mutilation of body parts (blinding, cutting off one's ears, nose, hand), cruel corporal punishment (branding, scorching of one's hair and beard, flogging), imprisonment, severe fines, confiscation of property, exile, and collective responsibility.

The research methodology in this paper is based on the normative, dogmatic and historical methods. The article presents and analyzes different rigorous criminal sanctions envisaged in Dušan's Code for members of different classes and different forms of punishment for criminal offenders. The author discusses the impact of this Code and the underlying RomanByzantine law on the development of subsequent Serbian criminal legislation, including the positive criminal legislation of the Republic of Serbia.

\section{LeGiSLATIVE Activity OF STEFAN DUŠAn (ON DUŠAN'S CODE)}

Stefan Uroš IV Dušan Nemanjić (c. 1308 - 1355) was the last Serbian king from the Nemanjić dynasty, who ruled from 1331 to 1346. On Easter, 16 April 1346 he became the first emperor of the Serbian-Greek Empire, when he was crowned by the first Serbian patriarch, Joanikije II (Stojanović, 1927:83). He was one of the most powerful monarchs of medieval times, highly respected among the Serbs to the present days. Little is known about the last days of Tsar Dušan's life, except that he died on 20 December 1355 and was buried in his endowment in the monastery of the Holy Archangels near Prizren (Rajić, 1975:151).

In 1349, Tsar Dušan enacted a very important legal document called "Tsar Dušan's Code" which regulated different aspects of secular and ecclesiastic life in medieval Serbia. 
The Code was proclaimed on 21 May 1349 in Skopje (the capital of the Empire), and it was written in the old Serbo-Slavic language, the first literary language of the Serbs.

The original manuscript of the Code has not been preserved but it has been reconstructed on the basis of transcripts (dating back to $14^{\text {th }}-18^{\text {th }}$ century), owing to the monastic tradition of copying manuscript. The most complete text is contained in the Hilandar, Bistrica and Prizren transcripts, which designate this legal document as: the Law of the true-believing Tsar Stefan Dušan. ${ }^{1}$ The content of the Code is diverse, seeking to cover almost all areas of secular and religious life, but different areas are given different attention. Considering Serbia's long legal tradition, some areas had already been relatively well regulated. Dušan's Code did not repeal or literally repeat the old legal provisions, which were regarded as the greatest authority and directly referred to in the Code.

Thus, the first 38 provisions refer to the church and mainly regulate the position and activities of the church and the clergy, as well as administration of particular issues pertaining to the monastic and secular life in the specific circumstances in Dušan's state (Ferjančić, Ćirković, 2005:229). The subsequent 25 articles refer to the position and obligations of noblemen and freemen, and related property issues. Here, Dušan and his legislators did not have general legal texts that they could refer to; as there were only individual legal acts created over a long period of time, the relations between the ruler and the noblemen were mainly regulated by customary law. The remaining part of the Code includes diverse provisions on administrative, criminal and civil law, where there is a notable effort to thematically group the articles but without a systematic approach which may be observed in the first part of the Code. The lack of provisions related to civil law issues is explained by the fact that this area was covered in the City Law (part of St. Sava's Nomocanon, the first collection of rules of the Serbian Orthodox Church written in simple folk language), Farmers' Law dealing with agricultural issues, and Emperor Justinian's Law (Corpus iuris civilis). Thus, Dušan's Code primarily focused on criminal law issues, including a rigorous system of punishment. Due to the prominent feudal class system, the aristocracy was privileged in relation to other strata of society; as a result, members of different classes were subjected to different forms of punishment for the commission of the same crime. The largest part of the Code was heavily influenced by the Byzantine legal tradition; it is best reflected in the principle of legality, which was directly transferred from Byzantine law and explicitly envisaged in several articles of Dušan's Code, but it is disputable how much impact this principle actually had in practice (Stojičić, 2005:325).

Along with St. Sava's Nomocanon (1219), the Emperor Dušan's Code (1349) is the most important legal document of medieval Serbia. One part of Dušan's Code was based on the Nomocanon, which Tsar Dušan directly referred to in Articles 6, 8, 11, 101, 109 and 196 of Dušan's Code. One third of the Code was based on relevant provisions of Byzantine law; thus, there is a great similarity between Articles 171 and 172 of the Code (on the independence of the judiciary) and relevant parts of Basilica, the $9^{\text {th }}$ century collection of laws of the Byzantine emperor Basil (books VII, 1, 16-17), which were a Byzantine revision of Justinian's Corpus iuris civilis from the $6^{\text {th }}$ century. The last third was based on the Serbian customary law tradition.

\footnotetext{
${ }^{1}$ See: Monumenta serbica (accessed 28.8.2020): The English translation of the Prizren transcript, available at $\mathrm{http} / / /$ monumentaserbica.branatomic.com/rukse/ruknew/prevod/priz_prevodE.php?a=1\#1; the English translation of the Bitrica transcript, available at http://serbiasos.blogspot.com/2012/05/history-of-serbia-code-of-tsar-dushan.html
} 


\section{CRIMINAL LAW IN DUŠAN'S CODE}

One of the most prominent features of the feudal class system, which is clearly reflected in Emperor Dušan's Code, is the privileged position of aristocracy in relation to other strata of society. The class differences may be observed in the criminal law provisions envisaging rather different forms of punishment for the commission of the same crime by a lord (nobleman) and a sebar (commoner, dependant peasantry). Thus, the Prizren transcript of Dušan's Code provides: "And if a commoner curses or insults a lord (nobleman) or a landlord (gentry), let him pay one hundred perpers and be singed (scorched). And if a lord or landlord curses or insults a commoner, let him to pay one hundred perpers" (Art. 55). However, in some cases, different punishment was also provided for members of the same class who differed in wealth and power; for example, "if a lord insults a lesser lord or landlord, let him pay one hundred perpers; and if a lesser lord or landlord insults a greater lord or landlord, let him pay one hundred perpers and be beaten with sticks" (Art. 50). The provision shows the obvious difference in the social status of lords (noblemen), landlords (landowners) and landed gentry (of lesser social standing); thus, a lord or landlord had to pay the same penalty (fine) in case he insulted or shamed another lord or landlord of an lesser social standing, but the lesser lord/landlord or gentry was additionally subjected to corporal punishment, even though he was a member of the privileged class.

On the other hand, there were criminal offenses where all perpetrators had an equal standing, irrespective of whether they belonged to the privileged or subordinate class. For example, "Whoever is found to have killed his father, mother, brother or his own child, let that murderer be burned at the stake" (Article 96). Similar forms of punishment were envisaged for criminal offenses against the church and clergy: "If a man kills a bishop, a monk or a priest, let him be killed and hanged" (Article 95), as well as for arson (Art. 99), for poisoning (Art. 109), for brigandry and theft (Article 149), etc.

Although Dušan's Code does not refer to legal standing (capacity to stand trial), such provisions can be found in Mateus Blastares' Syntagma Canonum (1335) and in the Procheiron enacted by the Byzantine Emperor Basils I (867-879 AD), which are both based on Justinian's Corpus iuris civilis. Relying on the Byzantine legal tradition, Dušan's Code includes a provision on drunkards who commit a criminal offence in a drunken state, where the intoxication is taken as an aggravating circumstance; thus, "If a drunken man attacks, cuts or wounds another, yet not to death, then shall one of his eyes be removed and one of his hands cut off. But if a drunkard molests, attacks or insults another but, does not make him bleed, he shall be flogged with one hundred strokes and thrown into the dungeon (incarcerated); when taken out of prison, he shall be flogged again and released " (Article 166).

As the largest part of Dušan's Code deals with criminal law, the legislator introduced a new legal term "transgression" (srb. "sagrešenije", rus. "prestuplenie") for disobeying or inobserving the orders of the Church (Article 4) or for violating the written laws provided in the Code (Article 171); the term entails a violation of moral norms or state orders that were deemed important for the state. Guilt (culpa), particularly in terms of establishing objective responsiblility, was an unknown term in Dusan's Code. However, under the influence of Roman-Byzantine law and church law (in particular), the notions of guilt (culpa) and the culprit's intent were introduced into the Slavic legal tradition (Ostrogorski, 1969:148). Dušan's Code includes several articles that clearly differentiate between intent and negligence: "Whoever commits murder without intention or violence, he shall pay three hundred perpers. But if a man kills intentionally, both his hands shall be cut off hands" 
(Article 87). As it was customary for the Tsar to send his lords to remote regions of the Empire to serve as his officials or envoys, the Code provides: "If a lord on duty, taken in for food and lodging, does any wrong to another with malice: plunders one's land, burns one's house or does some other mischief (misdemeanour), that region shall be taken from him and another shall not be given to him" (Article 57); thus, he was removed from the official duty and barred from acting on behalf of the Tsar.

\section{Collective ResponsibiLity}

Under Dušan's Code, criminal responsibility (liability) is mostly individual, although there are several articles that envisage collective responsibility for some crimes. This form of liability applied to family households, villages, counties/districts, surrounding settlements and neighboring regions.

\subsection{Collective responsibility of the family household}

The collective responsibility of the family household is envisaged in Article 52 and Article 71 of the Code. The former deals with the responsibility of the household for the crime of high treason committed by a member of a noble family, in which case his household is obliged to pay for his transgression (Article 52); it implies that the family members living in the same household were held accountable for paying all fines, taxes and charges incurred by another family member. Under Article 71, if a household member commits a crime, "be it a brother or son or kinsman, who dwells in the same house, let the master of the house pay all dues or hand over the one who committed the crime" (Article 71); this article enables the landlord to choose whether to surrender a family member or to pay a fine for the committed crime. In both cases, the Code prescribes the objective responsibility of the family elder for the crimes committed by his family members, while Article 71 also prescribes personal performance, i.e. delivery of the culprit by the person in charge of the household.

\subsection{Collective responsibility of the village}

A number of provisions of Dušan's Code provide for the responsibility of the village for various crimes: taking the dead out of the graves (Article 20), failing to bring a person who has committed a crime before a judge (Article 92), harbouring thieves and robbers in the village (Article 145), denying lodging and overnight stay in the village to travelling merchants (Article 159), harbouring goldsmiths who secretly mint money without the Tsar's authorization (Article 169), etc. It is obvious that the legislator did not into consideration the natural person who committed the crime, but resorted to punishing the entire village, which was held accountable under the principle of collective responsibility for the commission of any crime on its territory. Although the unauthorized goldsmith was subject to individual punishment (branding), while the thief was blinded and robber were hanged, it does not diminish the absurdity of the collective responsibility of the entire village which was obliged to pay a fine to the state (emperor) even if the delinquent was apprehended.

\subsection{Collective responsibility of the neighboring county or district}

This form of collective responsibility is also quite common in Dušan's Code. Article 58 provides for the protection of the property of the deceased landlord who owns a village in 
a (remote) district; thus, in case of any damage to his property (by fire, looting, etc.) the whole district was obliged to pay for the damage. Article 100 envisages that, in case anyone outside a village commits arson (by setting fire to hay in the local thrashing grounds), the neighbouring villages have to pay the damage or hand over the arsonist. Similarly, if theft or robbery is committed on the city land outside the town walls at the outskirts of a town, the damage shall be paid by the neighbouring/surrounding settlements (Article 126). All villages in a district had a duty to safeguard the imperial property; thus, "if a thief steals the Tsar's pigs, the damage shall be paid by the neighbouring settlements" (Article 191), which also entails their duty to find and bring to justice all thieves and robbers who happen to be on their territory. Villages and counties were also obliged of guard roads and keep the watch on unpopulated hills; if they failed to perform the duty, any damage caused by theft/robbery or a fine imposed for the committed crime was to be paid by the surrounding villages in charge of keeping the watch (Article 158).

\section{CRIMINAL SANCTIONS IN DUŠAN'S CODE}

In medieval times, revenge in blood (bloodshed) was a common way of punishing the perpetrator of a crime of murder. In Dušan's Code, it was replaced by the criminal sanctions and penalties, which were explicitly envisaged and enforced by the state. The customary law institute of " $v r a z ̌ d a$ ” (wergild, man price or blood money); was preserved in Serbia for a very long time (Janković, 1962:87); it implied that the perpetrator of the crime of murder was obliged to pay a punitive charge for bloodshed to the family of the murdered person as compensation and redemption for bloodshed, which shall end the blood feud. A fine ('globa") was envisaged for misdemeanours and it was paid to the state, not to the injured party. Instead of money, the fine could also be paid in kind (e.g. cattle), which was a remnant of the ancient tradition.

Dušan's Code accepted the Byzantine system of punishment. One of the main purposes of punishment in the Middle Ages was retaliation. In addition, public execution of harsh corporal punishment served as general and special prevention. Correction of the culprit was envisaged but it was not considered to be a duty of the state. In accordance with the doctrine of repentance of sins, the church took on this duty, using for that purpose a complex system of church penances in addition to the regular state-envisaged punishment (Solovjev, 1980:157). Wanting to bring this idea into secular law, the church recommended imposing punishments that give the "sinner" time to repent (Taranovski, 1931:5).

Dušan's Code envisaged the following criminal sanctions: death penalty, mutilation of body parts by which the crime was committed, severe corporal punishment, branding, scorching one's hair and beard, exile and banishment, incarceration (in the dungeon), "vražda" (wergild, a punitive charge for bloodshed), fines, confiscation of property, loss of honorary rights, etc.

\subsection{Death penalty}

Death penalty is a legal sanction whose execution results in the death of the convicted offender. It is considered to be one of the oldest criminal law institutes, given that for a long time it was the only means that ancient human societies had at their disposal for maintaining law and order. Alternatives to death penalty, such as (life) imprisonment were eventually instituted, in line with the development of the state and its institutions. 


\subsection{1. "To kill"}

Death penalty was envisaged in Dušan Code (in Articles 86, 95, 130 and 131) and extensively practiced. Article 86 prescribes: "When there is a homicide, he is held guilty who provoked it, even if he be killed himself"; such a provision was aimed at securing the payment of a fine by the family of the guilty man who got killed. Article 95 prescribes that anyone who kills a bishop, a monk or a priest shall be killed and hanged. Articles 130 and 131 refer to soldiers' conduct in war and peace. Article 130 prescribes "whoever in the army destroys a church, shall be killed and hanged"; this provision referred to both imperial and enemy soldiers' conduct during the war. In a way, this provision way a precursor to the current Geneva Convention because it sanctioned one of the grave war crimes.

\subsection{2. "To burn"}

Death by burning at the stake was envisaged in several articles. Thus, Article 96 prescribes: "Whoever kills his father, mother, brother or own child, let that murderer be burnt in the fire". A similar punishment is envisaged in Article 169, which provides that a goldsmith secretly forging or minting money without the ruler's authorization shall be branded (with a scorchinghot branding iron), whereas the village or the city harbouring him had to bear collective responsibility; yet, the imposed punishment was different: while the city was obliged to pay a fine, the village was "scattered" (which implies that the village was burnt down and disbanded, the people were deprived of their property and compelled to disperse).

\subsection{3. "To hang"}

Article 53 of Dušan's Code provides for the criminal offense of rape. Thus, "if a sebar (commoner) takes a noblewoman (landlady) by force, let him he hanged"; however, if a lord/landlord take a noblewoman/landlady by force, or if a commoner takes his own equal by force, the punishment is the same: the rapist shall have "both his hands cut off and his nose slit". It can be noted that the Code does not provide for the case of rape of a female commoner by a landowner, so these cases may have been regulated by customary law or may not have been punishable. Death by hanging was also envisaged for brigands/robbers; Article 145 envisages: "In whatever village a thief or brigand be found, that village shall be "scattered" and the brigand shall be hanged forthwith, while a thief shall be blinded"; in addition to the envisaged collective responsibility of the village, this article envisages that the head of the village who shall pay all the damage caused by the robber or thief and "shall be punished as a thief and a brigand". Moreover, Article 149 explicitly states that the thieves and brigands caught in the act "shall not be pardoned but blinded and hanged" (respectively).

\subsection{Mutilation of body parts by which a criminal offense was committed}

Corporal punishment was rather common in medieval period. It often included very cruel forms of punishment, such as: burning or branding; cutting off one's hand(s), ear(s), nose and tongue; blinding; beating or flogging, scarring or bruising, etc. The orders were made and enforced without delay. Almost all mutilation punishments contained in Dušan's Code were transposed from Byzantine law; castration is the only one which was left out. Mutilation generally entailed inflicting bodily harm to the part of the body by means of which the crime was committed. Thus, the criminal punishment of having a hand "to cut off" was provided in Articles 21, 53, 54, 87, 94, 97162 and 166 of the Code. The criminal 
punishment of having both hands cut off was imposed for serious transgressions and disobedience, and often accompanied by another mutilation. Thus, the Code envisaged as follows: the one who sells a Christian to a non-Christian shall have both hands cut off and his tongue taken out (Article 21); if a lord/landlord and a commoner rapes a woman of his own social status, he shall have his both hands cut off and his nose slit (Article 53); if a noblewoman/landlady commits fornication with her man, "the hands of both shall be cut off and their noses slit" (Article 54); if commoners meet in assembly or council, their ears shall be cut off and their face singed (scorched) (Article 69); if a person commits a deliberate (intentional) murder, both his hands shall be cut off (Article 87); if a commoner kills a landowner, "he shall pay 300 perpers and both his hands shall be cut off" (Article 94); if one plucks the beard of a lord/landlord (a symbol of dignity and honour), both his hands shall be cut off (Article 97); if a thief is found in a village, he shall be blinded, and the head of the village shall pay all the damage caused by thief and shall be punished as a thief (Article 145); a state official sent on official duty or business across the land is authorized by a court or imperial writ; if he is found to have tampered with the writ or acted contrary to the writ, his both hands shall be cut off and his tongue slit (Article 162); if a drunkard strikes, cuts or wounds another, he shall have one eye removed and one hand cut off (Article 166).

\subsection{Beating and Flogging}

If a commoner (sebar) utters heretical words (commonly referred to as the "Baboon words" of Bogomiles/heretics, discussing religious dogmas, criticizing the church, preaching equality, disobedience to the authorities, etc.), "let him pay 12 perpers and be beaten with sticks" (Article 85). In case a lesser lord/landlord curses, insults or shames a greater one, he shall pay 100 perpers and be beaten with sticks (Article 50). Article 131 prohibits quarrels and fights in the army; thus, in case two soldiers start fighting, others shall let them fight; "if anyone who joins the fight or comes to their assistance, he shall be flogged"(Article 131). If a drunkard molests and insults another without wounding him, he shall be flogged with 100 strokes and "cast in the dungeon"; once taken out of prison, "he shall be flogged again and released" (Article 166).

\subsection{Scorching one's hair or beard}

This form of punishment is provided for commoners who curse or insult a lord/landlord, in which case they are to pay 100 perpers and "be singed" (Article 55), by scorching one's hair, beard or mustache. If commoners meet in council (assembly), their ears shall be cut off and faces singed (Article 69). Moreover, if a meropah (dependant peasant, a serf) flees from his landlord to another country or to the Emperor's land, he shall be singed and his nose slit (Article 201).

\subsection{Exile and Banishment}

Article 9 of the Code prescribes punishment for "a half-believer", a Latin who is not a pagan or completely Christian. Thus, "if a half-believer takes a Christian woman as his wife, he shall be baptized into Christianity; if he is not baptized, his wife and children shall be taken from him and they shall be allotted a part of his house but he shall be driven forth" (expelled). Article 10 prescribes punishment for heretics (the sect of Bogumiles) who are 
found to be living among Christians; they are to be branded on the face and expelled, while the person who harbours them shall be branded (Article 10). Article 11 regulates the appointment of clergymen in parishes who received a blessing from bishops; if they are not appointed as clergymen, they shall be expelled and punished by the church according to the law. In addition, "monks and nuns who are sworn and live in their own homes shall be driven away and shall live in the monasteries" (Article 17).

\subsection{Vražda and Fine}

"Vražda" (wergild, man price, blood money) is an archaic customary law institute which entails a payment of a punitive charge or fine for murder (bloodshed), partly in favor of the state and partly in favor of the injured party (family of the murdered person) as compensation and redemption for bloodshed, which shall end the blood feud. "Vražda" is explicitly envisaged in Dušan's Code in Article 20 (on heretics who burn the bodies of the dead), which prescribes: "If any person be taken out of his grave by sorcery and be burnt, any village that does this shall pay a fine" (vraža, a fine for removing the corpses from graves and burning them); "if any priest shall come to it, let his priesthood be taken from him" (Article 20). In Article 103 (on the trial of slaves) and Article 183 (on emperor's shepherds), it is mentioned as a legal ground for going to court for criminal offences. Article 154 prescribes a punitive charge ( $v r a z ̌ d a)$ imposed by the Emperor on jurors who acquit a person under oath but the person's guilt is subsequently proved; thus, "when jurors acquit some one on oath according to the law, and after the acquittal, guilt be proved genuinely against the one whom they have acquitted, let the Tsar exact from those jurors a fine of one thousand perpers each, and afterwards those jurors shall not be believed and they may not take either husband or wife" (Article 154).

Medieval Serbian law includes different terms for monetary penalties and fines imposed for the commission of various crimes. Notably, the fine of "paying sevenfold" is envisaged in seven articles of Dušan's Code: for molesting a monk or a man of the Church (Article 30); for enticing a neighbour's man to work in another's property (Article 93) ; for cautionary deposits for estimated pecuniary damage (for felling timber, poaching, stray cattle, land disputes) (Article 102); for wardens of marches (frontier provinces) who fail to bring to justice brigands passing through their territories with booty robbed elsewhere (Article 143); for Tsar's senior official in charge of a "scattered" village in case anyone returns to the village and spends a night there, in contravention of the Tsar's law (Article 187), for anyone who fails to participate in "svod" (archaic evidentiary proceeding involving parties' confrontation) in lawsuits pertaining to stolen or wrongfully seized horses, cattle or other property (Article 193); finally, Article 200 provides for sevenfold compensation for deceit; thus, "if a man is found in another land, where his horse dies, gets eaten by wolves, or gets killed by the man himself, but he takes lodging for the (dead) horse, and the truth is later revealed, then the man's master/landlord shall pay seven horses to the lord of that land", as a fine for fraud (Article 200).

In Emperor Dušan's times, a fine was paid in perpers. Depending on the criminal offense, the prescribed amount ranged from $6,12,100,300,500$ to a thousand perpers. Article 85

\footnotetext{
2 "Svod" is an archaic pan-Slavic evidentiary and procedural instrument, which was commonly used in property lawuits (related to horses, cattle and other wrongfully taken or stolen assets); it entailed a face-to-face confrontation of the rightful owner/possessor (claimant) and the wrongful possessor (defendant), where the later had to prove legal title to his possession. For more, see: Đorđević, 2008: 204.
} 
stipulates: if a commoner (sebar) "utters Baboon words" (i.e. uses heretical language, criticizes the church, preaches equality and disobedience to the authorities), he shall pay 12 perpers and be beaten with a stick. In case a lesser lord curses, insults or shames a greater one, he shall pay 100 perpers and be beaten with sticks (Article 50). As boundary disputes between adjacent neighbours were common, Article 77 envisaged a fine of 50 perpers ("potka") for a violation of real estate boundary lines between villages, half of which was to be paid to the Tsar and the other half to the village. Several provisions also refer to the border territories and crimes committed by the Vlachs and Arbanassi, who were considered secondclass subjects at that time. Thus, Article 77 envisages a fine of 100 perpers ("potka") if the Vlachs and Arbanassi were found guilty of violating the village boundaries. Aware of the quarrelsome nature of these two nations, Tsar Dušan tried to prevent possible conflicts. Thus, Article 82 prohibited shepherds/herdsmen to spend the night in the villages where Arbanassi and Vlachs took lodging; anyone who violated this ban was to pay a fine of 100 perpers ("potka") and the value of the grass grazed by his cattle.

A fine of 300 perpers was to be paid in several cases: by a layman who was found to have adjudicated in an ecclesiastical matter, given that "only the Church shall judge" in such matters (Article 12); by a person who committed a negligent murder, without intention and violence (Article 87); by a commoner who murders a lord, whereby the sebar also has his both hands cut off (Article 94); and by a landowner or a customs officer who detains a merchant (Article 122).

A fine of 500 perpers was to be paid in two cases: by anyone who molests travelling merchants, robs them or scatters their merchandise, and seizes their money or merchandise by force (Article 118); and by lords (noblemen) and city heads ("kefalije", prefects) in charge of towns and market-places who cast any man in the dungeon without the Tsar's warrant (writ) and against the Tsar's order (Article 184).

A fine of 1,000 perpers was envisaged in two cases: first, if a lord (nobleman) kills a commoner (sebar) in the city, county or district (Article 94); and second, if sworn jurors acquit a person acceding to the law but the person's guilt is proved after the (wrongful) acquittal, the Emperor fines the jurors with a punitive fine ("vražda") of 1,000 perpers, they shall no longer be trusted, and none of them may get married (Article 154).

Instead of being paid in money, the imposed fine was sometimes paid in kind (e.g. cattle), which is a remnant of the ancient past. Article 56 prescribes a fine for default ("prestoj"), i.e. failing to appear in court; it reads: "a lord shall not be summoned to court in the evening; he shall be summoned before dinner by the bailiff (executive officer of the court), and if he does not come by dinner time, he is at fault and from that lord six oxen shall be taken" (Article 56). Article 76 refers to stray cattle; thus, if one's cattle trespass on another's field, vineyard or a meadow by mistake (unintentionally), the cattle owner will have to pay the amount of damage that is assessed at face value (by evaluators who establish the value on their conviction); but if the trespass was deliberate, the cattle owner had to pay six oxen for the trespass.

\subsection{Confiscation of property}

Confiscation of property was envisage as a form of punishment in several cases. Article 111 envisages penalty for insulting or discrediting judges (i.e. for contempt of court and judicial authority and dignity); thus, if a judge is insulted and shamed by a lord, he shall be deprived of all property; if a judge is insulted or shamed by a village, "let it be scattered 
and confiscated." Confiscation of property was also envisaged as punishment for any person who refuses to receive the judicial herald or bailiff who serves writs and the executive officer appointed by the judge to investigate the case (Article 107). It could also be applied to the entire village; thus, if a robber or a thief is found in the village, "the village shall be scattered, the brigands shall be hanged upside-down, the thief shall be blinded, the head of the village shall be brought to the imperial court and he shall pay for all damage caused by the brigand, and he shall be punished as a thief and a brigand" (Article 145).

\subsection{Incarceration (in the dungeon)}

The penalty of deprivation of liberty (imprisonment) is not mentioned in Dušan's Code as the main punishment or as the common secondary punishment. Yet, two provisions mention the "dungeon": Article 19 prescribes that "a monk who casts off his monastic dress (abandons his faith) shall be kept in prison until he returns to obedience"; Article 166 provides for a drunkard "to be thrown into a dungeon". The period of imprisonment is not specified in either case.

Ostrogorski noted that "there was a large number of dungeons on church, aristocratic and state estates, at the imperial and patriarch's court. The dungeons were probably used both for interrogation and imprisonment of the accused and other subjects for various violations of their duties. Obviously, the dungeon was not only a prison for serving sentences but was also used for pre-trial detention and as a coercive means of collecting fines and all kinds of duties" (Ostrogorski, 1969:67).

Dušan's Code recognized several types of dungeons: patrimonial, church, aristocratic and state dungeons, as well as dungeons at the patriarch's (church) court and at the imperial court. Deprivation of liberty was envisaged as a measure for keeping the accused in custody or incarceration of the convicted person, but also for imprisoning tardy debtors.

\section{CONCLUSION}

In the Middle Ages, the time of constant decline of Byzantium, both in territorial and economic terms, was the time of steady rise of Serbia. While Byzantium was torn apart by civil wars, destroyed by attacks of external enemies, Serbia expanded territorially and strengthened economically. When he came to power in 1331, Tsar Stefan Dušan clearly outlined the goals of his rule. From that moment until his death, he consistently expand his state which, during his rule, covered the largest territory in Serbian history. One of the most prominent features of his rule was the extensive legislative activity on enacting Dušan's Code, one of the most important legal documents in Serbian history, which is regarded as the constitution of medieval Serbia.

Emperor Dušan's Code regulated different aspect of life in the Serbian-Greek Empire, including the position and activities of the church and the clergy, the position and obligations of noblemen and commoners, as well as diverse administrative, criminal and civil law issues. Yet, the largest part of the Code refers to criminal law, rigorous criminal sanctions and diverse forms of punishment which were imposed on the perpetrators of criminal acts in medieval times.

One of the most prominent characteristic of the feudal class system was reflected in the privileged position of nobility and particularly in different forms of punishment for members of different classes (noblemen, commoners, serfs, slaves), which has been illustrated in the 
provided analysis of relevant articles of Dušan's Code. However, the Code is significant because it influenced the development of Serbian legislations in the centuries to come, to the present day.

As far as criminal law is concerned, we may briefly outline the key contributions of this Code to the Serbian criminal law as well as the major differences between Dušan's Code (1349) and the contemporary Criminal Code of the Republic of Serbia of 2006, currently in force. While Dušan's Code envisaged different forms of punishment for the commission of the same crime for members of different classes, the criminal sanctions envisaged in the current Criminal Code are the same for everyone, regardless of citizens' status, national or ethnic affiliation or personal characteristics. The concept of guilt (culpability) established on the principle of objective responsibility was unknown in Dušan's Code, which heavily relied on the Byzantine legal tradition and Serbian customary law. However, under the influence of the rigorous provisions of Roman-Byzantine law and particularly the ecclesiastical (church) law, the Slavic people had quite an accurate notion of "transgression", deliberate and negligent conduct, rightful and wrongful possession, lawful and unlawful activities (etc.). As illustrated in this paper, they were all part of Dušan's Code. However, the archaic legal institutes and archaic terminology (e.g. sagrešenije, svod, vražda, potka, globa, prestoj) are no longer part of Serbian law.

A major difference between Dušan's Code and the current Serbian Criminal Code is the institute of collective responsibility, which is not part of the positive Serbian law. In Dušan's Code, collective responsibility was prescribed as a form of punishment for specific crimes (theft, robbery, brigandry) where the culprit was on the loose; in order to compensate for the damage, injury or harm incurred by a community member or another, the Empire imposed the obligation on family households, villages, counties, districts, surrounding settlements or neighboring regions to pay different fines (as penalty or compensation), to deliver the culprit, and to ensure the protection of private property as well as imperial property. Under the contemporary legislation, no one can be held criminally liable for illegal actions committed by another person, considering the fact that criminal liability is exclusively individual in the current Serbian law.

As for criminal sanctions and forms of punishment, we can conclude that criminal sanctions were much more rigorous in medieval times than those envisaged in the current Serbian criminal legislation. While death penalty (by killing, hanging or burning) was prescribed for a number of criminal offenses in medieval times, it is not envisaged for any criminal offense in the current Serbian Criminal Code, which includes life imprisonment, imprisonment (up to 40 years), monetary penalty (fine), community service, and confiscation of the driving licence (Article $43 \mathrm{CC}$ ), as well as a range of cautionary, safety, correctional and educational measures (Article 4 CC). Similarly, cruel corporal punishment (branding, beating, flogging, scorching) and mutilation of body parts by which the crime was committed (cutting off one's hand(s), ear(s), nose or tongue) were quite common in Dušan's Code, whereas none of them are part of any contemporary legislation, nor Serbian law. As a matter of fact, nowadays such practices constitute a serious violation of the universally guaranteed human rights envisaged in many contemporary international and national legal documents.

The only similarity between Dušan's Code and the current Serbian Criminal Code may be found in the system of monetary penalties (fines). Dušan's Code contains a range of fines (vražda, potka, globa, prestoj) for the commission of different criminal offences, which were paid in perpers; depending on the type of committed crime, fines ranged from 6 perpers to 1,000 perpers. These archaic types of fine are no longer part of the current Serbian legislation. 
Nowadays, a fine may be awarded as a primary or a secondary form of punishment, ranging from 10,000 RSD to 10 million RSD (Article $50 \mathrm{CC}$ ), depending on the committed criminal offence. It has to be paid within a given time limit, in full or in installments, In case of failure to pay in time, a fine may be replaced by a prison sentence or community service (Article 51 CC). Under specific circumstances, the Serbian Criminal Code provides for the mitigation of punishment (Article $56 \mathrm{CC}$ ), exoneration (Article $58 \mathrm{CC}$ ) and settlement (Article $59 \mathrm{CC}$ ). Thus, the current Serbian criminal legislation provides some alternative solutions which were not envisaged in Dušan's Code.

\section{REFERENCES}

Avramović, S. (2000) Opšta pravna istorija-stari i srednji vek (General legal history of the Ancient Times and the Middle Ages), Pravni fakultet, Univerzitet u Beogradu, Beograd, 2000.

Đorđević, A. (2008). Dokazno sredstvo "svod" u sudskom postupku kod Slovena (Evidentiary Instrument in Court Proceedings in the Slavic Legal Tradition), Zbornik radova Pravnog fakulteta u Nisu, br. 51, 2008, pp.197207, available at http://www.prafak.ni.ac.rs/files/zbornik/sadrzaj/zbornici/z51/10z51.pdf

Frejančić, B.; Ćirković, S (2005) Stefan Dušan-kralj i car (Stefan Dušan- king and emperor) Zavod za udžbenike, Beograd, 2005.

Janković, D. (1962) Srpska feudalna država od XII do XV vek (the Serbian feudal state from the $12^{\text {th }}-15^{\text {th }}$ century), Prosveta SKZ, Beograd, 1962.

Jevtić, D.; Popović, D. (2000). Narodna pravna istorija (People's legal history), Savremena administracija, Beograd, 2000.

Jovašević, D. (2006). Leksikon krivičnog prava (Lexicon of Criminal Law), Službeni glasnik Beograd.

Kostrenić, M. (1951) Dušanov zakonik kao odraz stvarnosti svog vremena (Dušan's Code as a reflection of reality of the time), Zbornik u čast šeste stogodišnjice Zakonika cara Dušana, Srpska akademija nauka (SANU), Beograd, 1951.

Nikolić, D. (1997) Fragmenti pravne istorije (Fragmenta historiae iuris), Institut za pravna i društvena istraživanja Pravnog fakulteta u Nišu, Niš, 1997.

Nikolić, D. (2000) Drevnorusko slovensko pravo, (Ancient Russian Slavic Law), Službeni list SRJ, Beograd, 2000.

Nikolić, D.; Đorđević, A. (2002) Zakonski testovi starog i srednjeg veka (Codes of Ancient Times and the Middle Ages), Bona fides, Niš, 2002.

Novaković, S. (1878) Zakonik Stefana Dušana cara srpskog 1349. i 1354. (Dušan's Code of 1349 and 1354), Izdanje zadužbine Ilije M. Kolarca, Beograd, 1878.

Novaković, S. (1893) Strumska oblast u XIV veku i car Dušan (Struma Region in the $14^{\text {th }}$ century and Tsar Dušan), Glas SKA 36, Beograd, 1893.

Ostrogorski, G. (1969) Istorija Vizantije (History of Byzantium), Izdavačko preduzeće Srbije Prosveta, Beograd, 1969.

Radojčić, N. (1924) Snaga zakona po Dušanovom zakoniku (The Force of Law in Dusan's Code), Glas SKA CX, Beograd, 1924.

Radojčić, N. (1951) Dušanov zakonik i vizantijsko pravo (Dušan's Code and Byzantine Law), Zbornik u čast šeste stogodišnjice Zakonika cara Dušana, SANU, Beograd, 1951, str: 45

Radojčić, G. (2006) Bibliografija o zakonodavstvu cara Stefana Dušana (Bibliography on the legislation of Tsar Stefan Dusan), Izvori srpskog prava VII, SANU, Beograd.

Ransimen, S. (1964) Vizantijska civilizacija (Byzantine civilization), Minerva, Beograd, 1964.

Solovjev, A. (1926). Izabrani spomenici srpskog prava od 12. do 15.veka (Selected Serbian lrgsl documents from 12th -15th century), Izdavačko i knjižarsko preduzeće Geca Kon, Beograd, 1926.

Solovjev, A. (1926) Odabrani spomenici srpskog prava (Selected monuments of Serbian law), Geca Kon, Beograd.

Solovjev, A. (1928), Sebrov zbor (Sebers' Assembly), Arhiv za pravne i društvene nauke, Beograd, 1928

Solovjev, A. (1928), Postanak i značaj Dušanovog zakonika (The origin and significance of Dušan's Code), Dosije studio, Beograd.

Solovjev, A. (1980), Zakonik cara Dušana 1349. i 1354. (Dušan's Code of 1349 and 1354) Srpska akademija nauka i umetnosti, Beograd, 1980.

Stojičić, S. (2005), Srbija 1804-2004: Društvo, ekonomija, država, pravo, politika, kultura, religija (Serbia 18042004: Society, economy, state, law, politics, culture, religion), Zbornik radova Pravnog fakultet u Nisu, Centar za pulikacije, Pravi fakultet, Univerzitet u Nišu, str. 325 
Šarkić S. (2006) Ideja Rima u misli i delu cara Dušana (The idea of Rome in the opus of Emperor Dušan), Zbornik radova Pravnog fakulteta u Novom Sadu, Pravni fakultet, Univerzitet u Novom Sadu, str: 53.

Taranovski T. (1926) Dušanov zakonik i Dušanovo carstvo (Dušan's Code and Dušan's Empire), Matica srpska, Novi Sad, 1926.

Taranovski T. (1931) Istorija srpskog prava u Nemanjićkoj državi (History of Serbian law in the Nemanjić state), Novinsko izdavačka ustanova Službeni list SRJ, Beograd, 1931. Online Sources:

Krivični zakonik Republike Srbije (Criminal Code of the Republic of Serbia), Sl. glasnik RS, br. 85/2005, 88/2005-ispr., 107/2005-ispr., 72/2009, 111/2009, 121/2012, 104/2013, 108/2014, 94/2016, 35/2019, https://www.paragraf.rs/ propisi/krivicni-zakonik-2019.html

Monumenta Serbica: Душанов законик, Призренски рукопис [XVIв.]-prevod (posted by Brana Tomic), http://monumentaserbica.branatomic.com/rukse/ruknew/prevod/priz_prevodS.php?a=1, Dusan's Code: the Prizren transcript $\left(16^{\text {th }}\right.$ century), English translation, (accessed 28.8.2020) http://monumentaserbica.branatomic.com/rukse/ ruknew/prevod/priz_prevodE.php?a=1\#1;

\section{KRIVIČNE SANKCIJE U DUŠANOVOM ZAKONIKU}

Dušanov zakonik, najvažniji zakon srednjovekovne Srbije, koji je zbog svoje važnosti u praksi često nazivan $i$ "Ustavom" Srbije predviđa surov vizantijski sistem telesnih i smrtnih kazni. Kao česta kazna izricana je novčana globa (vražda), a česte imovinske kazne su bile kazna konfiskacije imovine $i$ raseljavanje sela, kao kolektivna kazna za zavisno stanovništvo. Takođe su česte i smrtne kazne - vešanjem ili spaljivanjem. Zakonik poznaje i telesne kazne, u koje spada batinanje, kazne sakaćenja (odsecanje ušiju, nosa, jezika, ruku), oslepljivanje, smuđenje kose i brade, žigosanje... Postojala je i kazna zatvora, tj. bacanja u tamnicu. Autor ovog članka je analizom Dušanovog zakonika, ukazao na sve vrste krivičnih sankcija koje su bile predviđene navedenim zakonskim tekstom i izricane učiniocima krivičnih dela. Prilikom izrade članka korišćeni su su normativni, dogmatski i istorijski metod. Na osnovu analize $i$ upoređivanja sa pozitivnim krivičnopravnim propisima Republike Srbije, došli smo do zaključka da su krivične sankcije iz Dušanovog zakonika bile dosta rigoroznije, što proističe prevashodno iz toga da većina krivičnih sankcija koje su tada izricane učiniocima krivičnih dela, današnji Krivični zakonik Republike Srbije iz 2006. godine ni ne predviđa, pre svega misleći na smrtnu kaznu i surove telesne kazne.

Ključne reči: Dušanov zakonik, krivične sankcije, kolektivna odgovornost, smrtna kazna, telesne kazne 